\title{
Anna Wichowska Determinanty dochodów własnych w budżetach kurczących się miast Polski w kontekście lokalnego rozwoju społeczno-gospodarczego
}

Determinants affecting own-source revenues in the budgets of shrinking Polish cities in the context of local socio-economic development

The aim of the article is to identify the determinants affecting own-source revenues in shrinking Polish cities in the context of local socio-economic development. The first section describes the research problem in Polish and foreign literature and focuses on explaining the relationship between own-source revenues and socio-economic development in a specific group of shrinking cities. The next section defines the research method and the scope of the research. The last part presents the results of the research which indicated that in the field of local socio-economic development the most important factors affecting own-source revenues of shrinking cities in Poland are factors related to entrepreneurship and the labour market. The whole article ends with a summary, which synthesises the results of the research and the presented literature, as well as identifies the areas that may pose a potential challenge for the authorities of shrinking cities in Poland in the context of increasing the share of own-source revenues in the total incomes of their budgets.

\begin{tabular}{|c|c|}
\hline DOI & https://doi.org/10.31268/StudiaBAS.2021.34 \\
\hline Słowa kluczowe & $\begin{array}{l}\text { dochody własne, autonomia finansowa, kurczące się miasta, lokalny } \\
\text { rozwój społeczno-gospodarczy, demografia }\end{array}$ \\
\hline Keywords & $\begin{array}{l}\text { own-source revenues, financial autonomy, shrinking cities, local } \\
\text { socio-economic development, demography }\end{array}$ \\
\hline 0 autorce & $\begin{array}{l}\text { doktor nauk społecznych w dyscyplinie ekonomia i finanse, adiunkt, } \\
\text { Uniwersytet Warmińsko-Mazurski w Olsztynie, Wydział Nauk } \\
\text { Ekonomicznych, Instytut Ekonomii i Finansów, Katedra Teorii } \\
\text { Ekonomii • } \square \text { anna.wichowska@uwm.edu.pl • } \\
\text { ORCID 0000-0003-2862-4424 }\end{array}$ \\
\hline
\end{tabular}

Artykuł został udostępniony na licencji Creative Commons - Uznanie Autorstwa 3.0 Polska (CC BY 3.0 PL).

\section{Wstęp}

Dochody własne, z racji ich ścisłego związku z tzw. bazą ekonomiczną jednostki samorządu terytorialnego (JST), determinowane są przez czynniki związane z warstwą społeczną, materialną oraz gospodarczą jednostki², które w znacznej mierze można utożsamić z czynnikami lokalnego rozwoju społeczno-gospodarczego ${ }^{3}$. Wśród nich niezwykle istotna jest sytuacja demograficzna.

1 Szerzej o determinantach budżetów gmin, w tym dochodów własnych, w: A. Wichowska, Determinanty budżetów gmin na przykładzie województwa warmińsko-mazurskiego, Wydawnictwo Uniwersytetu Warmińsko-Mazurskiego w Olsztynie, Olsztyn 2020.

2 J. Parysek, Miasto w ujęciu systemowym, „Ruch Prawniczy, Ekonomiczny i Socjologiczny" 2015, t. 77, nr 1, s. 27-53, https://doi.org/10.14746/rpeis.2015.77.1.3.

3 A.P. Wiatrak, Determinants of Local Development Strategies, „Acta Scientiarum Polonorum. Oeconomia” 2018, nr 17(1), s. 113-120, https://doi.org/10.22630/ASPE.2018.17.1.13; A. Simms, D. Freshwater, J. Ward, The Rural 
W ostatnich latach wiele miast w Polsce doświadcza systematycznego ubytku mieszkańców, co ma wpływ na wszystkie aspekty funkcjonowania tych ośrodków, w tym na ich finanse, zwłaszcza na dochody własne, które zajmują szczególne miejsce w strukturze budżetu

W literaturze przedmiotu proces systematycznego zmniejszania się liczby mieszkańców ośrodków miejskich określany jest mianem kurczenia się miast ${ }^{5}$. Problem ten jest wieloaspektowy, ma złożoną naturę ${ }^{6} \mathrm{i}$ - jak podkreślają niektórzy autorzy - pozostaje nadal niewystarczająco zbadany ${ }^{7}$. Każdorazowe podejmowanie go stanowi ważne wyzwanie nie tylko teoretyczne, lecz także praktyczne ze względu na szerokie konsekwencje tego procesu i konieczność prowadzenia odpowiednich działań, które będą przeciwdziałały destabilizacji funkcjonowania miast oraz stymulowały ich rozwój społeczno-gospodarczy.

W związku z powyższym celem artykułu była identyfikacja najważniejszych determinant lokalnego rozwoju społeczno-gospodarczego powiązanych z dochodami własnymi w kurczących się miastach Polski. Pozwoli ona na wskazanie obszarów, które powinny być szczególnie ważnym polem aktywności władz lokalnych w zakresie lokalnej polityki ekonomicznej i ludnościowej, mającej przyczynić się do utrzymania niezależności dochodowej oraz ciągłości realizacji zadań publicznych miast. W artykule przyjęto hipotezę badawczą korespondującą z celem badań, tzn. istnienia statystycznie istotnego związku pomiędzy czynnikami z zakresu lokalnego rozwoju społeczno-gospodarczego a poziomem dochodów własnych w kurczących się miastach w Polsce.

W badaniach wykorzystano regresję liniową, która prowadzi do stworzenia modelu ekonometrycznego. Dzięki tej metodzie możliwe jest stworzenie równania opisującego związek zmiennej objaśnianej oraz zmiennych objaśniających. Za zmienną objaśnianą w badaniach przyjęto udział dochodów własnych w dochodach ogółem, natomiast potencjalnymi zmiennymi objaśniającymi były zmienne charakteryzujące lokalny rozwój społeczno-gospodarczy miast. Problem podjęty w artykule jest aktualny i ważny, ponieważ kurczenie się miast Polski, bez prowadzenia odpowiedniej polityki, może mieć wiele niekorzystnych konsekwencji o różnorod-

Economic Capacity Index (RECI), a Benchmarking Tool to Support Community-Based Economic Development, „Economic Development Quarterly" 2014, t. 28, nr 4, s. 351-363, https://doi.org/10.1177/0891242413512672; C. Wong, Developing Indicators to Inform Local Economic Development in England, „Urban Studies” 2002, t. 39, nr 10, s. 1833-1863, https://doi.org/10.1080/0042098022000002984.

4 M. Gornowicz, A. Wichowska, Struktura demograficzna a dochody gmin województwa warmińsko-mazurskiego w latach 2010-2014, "Społeczeństwo i Ekonomia” 2017, nr 1(7), s. 61-72; A. Wichowska, Demographic Determinants of Revenue Autonomy in Rural and Urban-Rural Municipalities, "Studia BAS” 2021, nr 1(65) [Źródła dochodów własnych jednostek samorządu terytorialnego w Polsce, red. P. Felis, M. Korolewska], s. 43-54, http://dx.doi.org/10.31268/StudiaBAS.2021.04.

5 T. Rieniets, Shrinking Cities: Causes and Effects of Urban Population Losses in the Twentieth Century , "Nature and Culture" 2009, nr 4(3), s. 233-235, https://doi.org/10.3167/nc.2009.040302; J.B. Hollander, K. Pallagst, T. Schwarz, F.J. Popper, Planning Shrinking Cities, „Progress in Planning” 2009, nr 72(4), s. 223-232.

6 K. Pallagst, T. Wiechmann, C. Martinez-Fernandez, Shrinking Cities: International Perspectives and Policy Implications, Routledge, New York-London 2013, s. 14; A. Bănică, M. Istrate, I. Muntele, Challenges for the Resilience Capacity of Romanian Shrinking Cities, "Sustainability” 2017, nr 9(12), 2289, s. 1, https://doi. org/10.3390/su9122289.

7 A. Wichowska, Economic Aspects of Shrinking Cities in Poland in the Context of Regional Sustainable Development, „Sustainability” 2021, nr 13(6), 3104, s. 1, https://doi.org/10.3390/su13063104. 
nym charakterze $i$ to na poziomie nie tylko lokalnym i regionalnym, lecz także krajowym, a więc może dotykać całej gospodarki. Proces ten prawdopodobnie będzie się nasilać w najbliższych dziesięcioleciach, na co wskazują prognozy Głównego Urzędu Statystycznego, który podaje, że do 2050 r. w aż 98\% miastach Polski liczba mieszkańców będzie malała .

\section{Konsekwencje kurczenia się miast dla ich dochodów własnych w kontekście lokalnego rozwoju społeczno-gospodarczego}

Problem systematycznego ubytku mieszkańców ośrodków miejskich, nazywany kurczeniem się miast, analizowany jest $\mathrm{w}$ literaturze przedmiotu od końca XX w. $^{9}$ Jest on powszechny i dotyczy wielu miast położonych na wszystkich kontynentach świata, które wcześniej były ważnymi i wielkimi ośrodkami przemysłowymi ${ }^{10}$. Miasta te po okresie szybkiego rozkwitu i boomu przeżywają obecnie kryzys, który przekłada się na różne aspekty życia społeczno-gospodarczego. Mimo wspólnej cechy tych miast - ubytku mieszkańców - tło procesu może być różne, dlatego analizy zjawiska często ograniczają się do np. jednego państwa, regionu lub konkretnych studiów przypadku¹1. Inaczej bowiem proces ten przebiega w miastach Europy Zachodniej, inaczej w krajach anglosaskich, w krajach Europy Centralnej i Europy Wschodniej, inaczej na terenie Azji. Warto dodatkowo podkreślić, że przyczyny i skutki kurczenia się miast nie są nadal w pełni rozpoznane, co jest spowodowane brakiem jednorodności tego procesu, jego złożonością oraz trudnościami metodycznymi ${ }^{12}$.

Proces kurczenia się miast jest ściśle związany z niekorzystnymi zjawiskami natury gospodarczej zachodzącymi na terenie tych ośrodków. Niektórzy autorzy definiujący kurczenie się miast oprócz ubytku ludności wskazują także na niekorzystne aspekty ekonomiczne tego procesu jako dwa komplementarne przejawy zjawiska ${ }^{13}$. Trudno jest jednak wskazać, który z tych przejawów jest przyczyną, a który skutkiem. Z pewnością istnieje między nimi sprzężenie zwrotne.

8 Główny Urząd Statystyczny, Prognoza ludności na lata 2014-2050, s. 110, https://stat.gov.pl/obszary-tematyczne/ludnosc/prognoza-ludnosci/prognoza-ludnosci-na-lata-2014-2050-opracowana-2014-r-1,5.html, 2014 [dostęp: 4 listopada 2021 r.].

9 A. Haase et al., Conceptualizing Urban Shrinkage, "Environment and Planning A" 2014, t. 46, nr 7, s. 1519-1534, https://doi.org/10.1068/a46269.

10 E. Jaroszewska, Urban Shrinkage and Regeneration of an Old Industrial City: The Case of Wałbrzych in Poland, „Quaestiones Geographicae" 2019, t. 38, nr 2, s. 75-90.

11 Przykładowo: C. Martinez-Fernandez et al., Shrinking Cities in Australia, Japan, Europe and the USA: From a Global Process to Local Policy Responses, „Progress in Planning” 2016, nr 105, s. 1-48, https://doi.org/10.1016/j. progress.2014.10.001; S. Döringer, Y. Uchiyama, M. Penker, M.R. Kohsaka, A Meta-Analysis of Shrinking Cities in Europe and Japan. Towards an Integrative Research Agenda, "European Planning Studies" 2020, t. 28, nr 9, s. 1693-1712, https://doi.org/10.1080/09654313.2019.1604635; Y. Long, K. Wu, Shrinking Cities in a Rapidly Urbanizing China, „Environment and Planning A” 2016, t. 48, nr 2, s. 220-222, https://doi. org/10.1177/0308518X15621631; K. Pallagst, Shrinking Cities in the United States of America. The Future of Shrinking Cities: Problems, Patterns and Strategies of Urban Transformation in a Global Context, University of California, California 2009

12 T. Rieniets, op. cit., s. 233-234.

13 M. Hartt, The Prevalence of Prosperous Shrinking Cities, „Annals of the American Association of Geographers", t. 109, nr 5, s. 1651-1653, https://doi.org/10.1080/24694452.2019.1580132. 
W kontekście lokalnego rozwoju społeczno-gospodarczego kurczących się miast można wskazać na obszary, które mogą być szczególnie powiązane z tym procesem i skutkować niekorzystnymi zmianami w finansach lokalnych. Najważniejszy ekonomiczny wskaźnik rozwoju gospodarczego to produkcja na danym terenie, która jest determinowana przez czynniki wskazane w tradycyjnych teoriach makroekonomicznych ${ }^{14}$, a więc np. przez poziom zatrudnienia, dochodów, konsumpcji oraz oszczędności. Ubytek mieszkańców miasta może się przekładać na wymienione czynniki i stanowić ich destymulant o charakterze zarówno ilościowym, jak i jakościowym. Negatywny wpływ ubytku mieszkańców miast może się przejawiać:

- w spadku podaży pracy oraz wydajności pracy na skutek migracji oraz starzenia się ludności,

- w spadku popytu na pracę na skutek ograniczania i przenoszenia działalności gospodarczej do innych miejsc,

- we wzroście udziału osób bezrobotnych oraz osób o niskim wykształceniu w ludności ogółem,

- w spadku dochodów mieszkańców,

- w pogłębianiu się dysproporcji dochodowych pomiędzy regionami,

- w spadku konsumpcji niektórych dóbr i usług ${ }^{15}$.

Powyższe czynniki R. Marks-Bielska i współautorki ${ }^{16}$, analizujące zmienne opisujące lokalny rozwój społeczno-gospodarczy, odnoszą do trzech grup, które określają jako: „przedsiębiorczość”, „sytuacja na rynku pracy” oraz „kwestie społeczno-demograficzne”. Oprócz tych grup wskazują także na „zagospodarowanie infrastrukturalne”. W ostatnich latach były prowadzone liczne badania także nad oddziaływaniem procesu kurczenia się miast na infrastrukturę miejską ${ }^{17}$. Skutkiem kurczenia się miast może być w pierwszej kolejności nie w pełni wykorzystywany zasób infrastrukturalny, zwłaszcza na obszarach peryferyjnych (np. infrastruktura drogowa), oraz wzmożone zapotrzebowanie na infrastrukturę w jego centrach, gdzie zazwyczaj przenoszą się mieszkańcy z uwagi na lepszą dostępność usług, co jest widoczne np. w Łodzi ${ }^{18}$. Ze względu na specyfikę infrastruktury miejskiej, np. wodno-kanalizacyjnej, koszt jej utrzymania może wzrastać z powodu mniejszej częstotliwości jej wykorzystania na obszarach wyludniających

14 J.E. Meade, A Neo-Classical Theory of Economic Growth, Routledge Revivals, London 2013, https://doi. org/10.4324/9780203106631.

15 A. Wichowska, Shrinking Municipalities and Their Budgetary Revenues on the Example of the Warmian-Masurian Voivodeship in Poland, „Oeconomia Copernicana” 2019, t. 10, nr 3, s. 421-422, https://doi.org/10.24136/ oc.2019.020.

16 R. Marks-Bielska, W. Lizińska, M. Wojarska, Raport z wykonania projektu badawczego. Sprawność instytucjonalna vs. Iokalny rozwój gospodarczy - czynniki kształtujqce i interakcje, Olsztyn 2017, s. 41-42, http://www.uwm. edu.pl/konferencjakpgir/pliki/raport_z_projektu.pdf [dostęp: 4 listopada 2021 r.]; M. Wojarska, R. Marks-Bielska, W. Lizińska, Institution Efficiency versus the Level of Development of Local Governments (a Study at the Level of Poland's Regional Division), "Acta Scientiarum Polonorum. Oeconomia” 2018, t. 17, nr 2, s. 142, https://doi.org/10.22630/ASPE.2018.17.2.29.

17 M. Hartt, op. cit., s. 1651-1670.

18 J. Kazimierczak, E. Szafrańska, Demographic and Morphological Shrinkage of Urban Neighbourhoods in a Post-Socialist City: The Case of Łódź, Poland, "Geografiska Annaler: Series B. Human Geography" 2019, t. 101, nr 2, s. 157, https://doi.org/10.1080/04353684.2019.1582304. 
$\operatorname{się}^{19}$. Rosnąć może także popyt na tzw. zielone inwestycje ${ }^{20}$. Powiązanym z kwestiami infrastrukturalnymi problemem jest niekorzystna sytuacja na rynku nieruchomości. Maleje popyt na mieszkania oraz pojawiają się drogie mieszkania w centrach miast i tanie, o niskim standardzie - na ich obrzeżach. Średnie ceny mieszkań i czynsze także maleją, ponadto ograniczane są inwestycje mieszkaniowe ${ }^{21}$. Pojawia się problem pustostanów i późniejszej ich rekultywacji22.

Opisane powyżej zjawiska wiążą się z sytuacją finansową miast, która oddziałuje na ich rozwój społeczno-gospodarczy ${ }^{23}$. Wielu autorów analizowało związek dochodów i wydatków budżetowych miast z ubytkiem ich mieszkańców. Konkluzje z tych badań sprowadzały się do tego, że ośrodki mogą być coraz bardziej zależne od transferów rządowych i tracić samodzielność dochodową na skutek negatywnych konsekwencji procesu kurczenia się miast ${ }^{24}$. W rezultacie problemy demograficzne oraz odpływ wykształconej części społeczeństwa mogą obciążać budżet centralny, z którego rozdysponowywane są środki dla jednostek samorządu terytorialnego, co z kolei może ograniczać transfery rządowe. Niekorzystne zjawiska demograficzne mogą mieć negatywny wpływ nie tylko na dochody własne JST, lecz także na wydatki budżetowe. W miastach, które ulegają kurczeniu się, mogą rosnąć bowiem wydatki na opiekę zdrowotną i pomoc społeczną. Konsekwencją tych wzrostów może być większa zależność od subwencji lub dotacji państwowych, a także konieczność zadłużenia się kurczących się miast ${ }^{25}$. Może to prowadzić do podniesienia podatków lokalnych, co z kolei może skutkować pogorszeniem konkurencyjności i atrakcyjności miast ${ }^{26}$.

Wpływ kurczenia się miast na ich dochody własne wynika z podatności tych dochodów na zmiany zachodzące w ich bazie ekonomicznej na skutek procesów demograficznych (migracji, naturalnego ruchu demograficznego, starzenia się społeczeństwa, obciążenia osób w wieku produkcyjnym osobami w wieku poprodukcyjnym, spadku dzietności, opóźnianiu decyzji matrymonialnych itp. $)^{27}$. Dochody własne polskich gmin charakteryzują się trzema cechami: są czerpa-

19 K.M. Faust, D.M. Abraham, S.P. McElmurry, Water and Wastewater Infrastructure Management in Shrinking Cities, „Public Works Management \& Policy" 2016, t. 21, nr 2, s. 128-156, https://doi.org/10.1177/1087724X15606737.

20 J. Schilling, J. Logan, Greening the Rust Belt: A Green Infrastructure Model for Right Sizing America's Shrinking Cities, "Journal of the American Planning Association” 2008, t. 74, nr 4, s. 451-466, https://doi. org/10.1080/01944360802354956.

21 E. Seymour, K.A. Endsley, R.S. Franklin, Differential Drivers of Rent Burden in Growing and Shrinking Cities, „Applied Geography”, nr 125, 102 302, s. 2-3, https://doi.org/10.1016/j.apgeog.2020.102302.

22 S. Burkholder, The New Ecology of Vacancy: Rethinking Land Use in Shrinking Cities, "Sustainability" 2012, t. 4, nr 6, s. 1154-1172, https://doi.org/10.3390/su4061154.

23 R. Marks-Bielska, W. Lizińska, M. Wojarska, op. cit., s. 41-42.

24 P. Franz, Shrinking Cities. Shrinking Economy? The Case of East Germany , "German Journal of Urban Studies" 2004, t. 43, nr 1; D. Coleman, R. Rowthorn, Who's Afraid of Population Decline? A Critical Examination of its Consequences, „Population and Development Review” 2011, t. 37, nr 1, https://doi.org/10.1111/j.17284457.2011.00385.x.

25 K. Großmann, M. Bontje, A. Haase, V. Mykhnenko, Shrinking Cities: Notes for the Further Research Agenda, "Cities" 2013, nr 35, s. 223, https://doi.org/10.1016/j.cities.2013.07.007.

26 M. Bernt, Partnerships for Demolition: The Governance of Urban Renewal in East Germany's Shrinking Cities, „International Journal of Urban and Regional Research", t. 33, nr 3, s. 755, https://doi.org/10.1111/j.14682427.2009.00856.x.

27 M. Gornowicz, A. Wichowska, op. cit., s. 61-72. 
ne ze źródeł zlokalizowanych na terenie gminy, w całości i bezterminowo są przekazywane do jej dyspozycji oraz pochodzą ze źródeł, na które jednostka może wywierać bezpośredni (aktywny) lub pośredni (bierny) wpływ, czyli nad którymi może sprawować tzw. władztwo podatkowe ${ }^{28}$. Wymienione cechy wskazują na to, że stan finansów lokalnych jest uzależniony m.in. od stopnia rozwoju społeczno-gospodarczego danej jednostki, a ten z kolei zależy od wielu czynników, na które wskazano uprzednio.

Źródłami dochodów budżetowych gmin w Polsce są wpływy z podatków i opłat lokalnych, udziały w podatkach od osób fizycznych i prawnych, dochody z majątku gminy i inne, np. spadki, zapisy, darowizny, kary, odsetki, a ponadto transfery z budżetu państwa: subwencja ogólna oraz dotacje celowe ${ }^{29}$. Najbardziej podatną na zmiany liczby ludności częścią dochodów budżetowych są wpływy podatkowe (zwłaszcza udziały w podatkach stanowiących dochody budżetu państwa), które stanowią najważniejszą część dochodów własnych miast.

\section{Metodyka badawcza i zakres badań}

Do oceny związku pomiędzy zmiennymi charakteryzującymi lokalny rozwój społeczno-gospodarczy a zmienną opisującą dochody własne kurczących się miast wykorzystano metodę regresji liniowej wielorakiej. Metoda ta służy do wykazania statystycznie istotnego związku liniowego pomiędzy zmienną objaśnianą i zmiennymi objaśniającymi. Umożliwia także wskazanie siły i kierunku tego związku dzięki interpretacji parametrów równania liniowego (modelu ekonometrycznego).

Zakres przestrzenny badań objął miasta (gminy miejskie) Polski, w których zaobserwowano systematyczny ubytek mieszkańców. Do identyfikacji tych miast posłużono się w pierwszej kolejności analizą dynamiki zmian liczby mieszkańców. W tym celu wykorzystano dane ludnościowe zgromadzone w Banku Danych Lokalnych Głównego Urzędu Statystycznego w Polsce ${ }^{30}$. Zakres czasowy badań objął lata 2015-2020. Uzasadnieniem wyboru okresu badawczego były inne analizy, w których wskazywano, że pięcioletni okres spadku liczby mieszkańców danego ośrodka miejskiego o minimum $0,5 \%$ rocznie jest wystarczający, by można było mówić o procesie jego kurczenia się ${ }^{31}$. W niniejszym opracowaniu zdecydowano się na trzy etapy badawcze. W pierwszej kolejności przeprowadzono analizę regresji w miastach, które odnotowywały stały ubytek mieszkańców przez wskazany okres. Kolejny, bardziej zawężony etap badań obejmował analizę regresji liniowej wielorakiej w miastach, w których ubytek mieszkańców był większy od wspomnianego poziomu 0,5\%, a następny etap dotyczył jedynie tych ośrodków, gdzie ubytek mieszkańców był większy od 0,75\%. Takie podejście miało na celu uszczegółowienie czynników,

28 P. Felis, Możliwości oddziaływania władz samorzadowych na wydajność wybranych kategorii źródeł dochodów własnych na przykładzie gmin w Polsce, "Finanse i Prawo Finansowe” 2014, nr 4, s. 37-51.

29 Konstytucja Rzeczypospolitej Polskiej z dnia 2 kwietnia 1997 r. (Dz.U. nr 78, poz. 483, ze zm.).

30 Bank Danych Lokalnych Głównego Urzędu Statystycznego, https://bdl.stat.gov.pl/BDL/ [dostęp: 14 września 2021 r.].

31 T. Stryjakiewicz, E. Jaroszewska, The Process of Shrinkage As a Challenge to Urban Governance, "Quaestiones Geographicae" 2016, t. 35, nr 2, s. 28, https://doi.org/10.1515/quageo-2016-0013. 
które wraz z nasilaniem się procesu kurczenia się miast będą miały największe znaczenie dla dochodów własnych tych ośrodków.

W przeprowadzonych badaniach za zmienną objaśnianą ( $Y$ ) przyjęto udział dochodów własnych w dochodach ogółem. Jest to podstawowy wskaźnik opisujący samodzielność dochodową gmin, który syntetycznie ujmuje wszystkie grupy dochodów własnych. Za zmienne objaśniane $\left(X_{n}\right)$ przyjęto wskaźniki, które odnoszą się do lokalnego rozwoju społeczno-gospodarczego. W badaniach posłużono się zmiennymi, które zaproponowała R. Marks-Bielska wraz ze współautorkami ${ }^{32}$. Ze względu na ścisły związek i pokrywanie się zmiennej $Y$ ze zmiennymi finansowymi, które autorki wzięły pod uwagę w swoich badaniach, zakres zmiennych został zawężony do 10 zmiennych z zakresu:

- zagospodarowania infrastrukturalnego: odsetek korzystających z instalacji kanalizacyjnej $\left(X_{1}\right)$, odsetek korzystających z instalacji wodociągowej $\left(X_{2}\right)$;

- przedsiębiorczości: liczba osób fizycznych prowadzących działalność gospodarczą na 100 osób w wieku produkcyjnym $\left(X_{3}\right)$, liczba podmiotów gospodarki narodowej w przeliczeniu na 1 tys. osób $\left(X_{4}\right)$, wartość relacji nowo zarejestrowanych podmiotów do podmiotów wykreślonych z rejestru REGON w przeliczeniu na 10 tys. ludności $\left(X_{5}\right)$;

- sytuacji na rynku pracy: udział zarejestrowanych bezrobotnych w liczbie ludności w wieku produkcyjnym $\left(X_{6}\right)$, udział osób pracujących w liczbie ludności w wieku produkcyjnym $\left(X_{7}\right)$;

- kwestii społeczno-demograficznych: liczba ludności w wieku poprodukcyjnym na 100 osób w wieku produkcyjnym $\left(X_{8}\right)$, saldo migracji wewnętrznych w gminie $\left(X_{9}\right)$, saldo migracji zagranicznych w gminie $\left(X_{10}\right)$.

Aby prawidłowo wnioskować na podstawie analizy regresji liniowej, muszą być spełnione założenia tej metody. W badaniach zostały one zweryfikowane za pomocą następujących testów:

- liniowość modelu względem parametrów (test RESET Ramseya),

- liczba obserwacji (miast) jest większa lub równa liczbie szacowanych parametrów,

- istotność parametrów (test t-Studenta),

- brak współliniowości parametrów (tzw. kryterium VIF, które powinno być mniejsze niż 10),

- oczekiwana wartość składnika losowego jest równa zero,

- składnik losowy jest homoskedastyczny (test White'a),

- składnik losowy ma rozkład normalny (test Doornika-Hansena) ${ }^{33}$.

Powyższe założenia przetestowano na poziomie istotności $p=0,05$. Obliczenia ekonometryczne wykonano w programie Gretl v. 2021b-git.

\section{Wyniki badań własnych}

Spośród istniejących w 2020 r. 302 gmin miejskich w Polsce w latach 2015-2020 procesowi kurczenia się ulegało aż 198 (66\%) miast. Stopniowy ubytek mieszkańców odnotowano w województwach: dolnośląskim (32\%), śląskim (30\%) oraz łódzkim (16\%) i lubelskim (15\%). W grupie

32 R. Marks-Bielska, W. Lizińska, M. Wojarska, op. cit., s. 41-42.

33 C. Brooks, Introductory Econometrics for Finance, Cambridge University Press, Cambridge 2008, s. 27-28. 
kurczących się miast Polski znalazły się aż 62 (21\%) ośrodki, w których ubytek mieszkańców był z roku na rok większy niż 0,5\%. W 17 (6\%) miastach natomiast ubytek ten wynosił ponad 0,75\%.

Jak wynika z przeprowadzonej analizy regresji liniowej wielorakiej, dochody własne były statystycznie istotnie powiązane z czynnikami lokalnego rozwoju społeczno-gospodarczego w kurczących się miastach Polski. Dowodzi to trafności hipotezy przyjętej w badaniach. W tabeli 1 zostały zaprezentowane szczegółowe wyniki badań dla trzech grup miast oraz spełnienie kryteriów prawidłowego wnioskowania na ich podstawie.

W badanym okresie we wszystkich miastach Polski odnotowujących stały ubytek mieszkańców determinantami udziału dochodów własnych w dochodach ogółem okazały się trzy czynniki z zakresu lokalnego rozwoju społeczno-gospodarczego. Były to:

- $X_{3}$ - liczba osób fizycznych prowadzących działalność gospodarczą na 100 osób w wieku produkcyjnym,

- $X_{6}$ - udział zarejestrowanych bezrobotnych w liczbie ludności w wieku produkcyjnym,

- $X_{7}$ - udział osób pracujących w liczbie ludności w wieku produkcyjnym.

Pozostałe potencjalne zmienne objaśniające nie weszły do modelu ze względu na brak istotnego związku ze zmienną objaśnianą. Równanie regresji liniowej wielorakiej można zapisać w następującej postaci:

$$
Y=44,83+0,77 X_{3}-1,16 X_{6}+0,09 X_{7}+e
$$

Jak wynika z zaprezentowanego równania, najsilniej z udziałem dochodów własnych w dochodach ogółem powiązana była zmienna $X_{6}$, czyli udział zarejestrowanych bezrobotnych w liczbie ludności w wieku produkcyjnym. Zależność ta była ujemna - jeśli udział zarejestrowanych bezrobotnych w liczbie ludności w wieku produkcyjnym wzrósłby o 1\%, to udział dochodów własnych w dochodach ogółem kurczących się miast zmalałby o 1,16\%. Kolejną zmienną pod względem siły związku ze zmienną objaśnianą okazała się $X_{3}$ - liczba osób fizycznych prowadzących działalność gospodarczą na 100 osób w wieku produkcyjnym. W jej przypadku zależność była dodatnia i oznaczała reakcję zmiennej $Y$ na poziomie 0,77\% w przypadku wzrostu zmiennej o 1\%. Trzecią w kolejności zmienną, najsłabiej powiązaną ze zmienną objaśnianą, była zmienna $X_{7}$ - udział osób pracujących w liczbie ludności w wieku produkcyjnym, której wzrost o 1\% mógł spowodować wzrost zmiennej $Y$ jedynie o 0,09\%.

W wynikach regresji liniowej wielorakiej dla 198 kurczących się miast Polski na uwagę zasługuje także współczynnik determinacji $R^{2}$, który wyniósł 42,4\%, a więc jego poziom jest relatywnie niski. Oznacza to, że zmienność zmiennej objaśnianej została wyjaśniona przez zmienność trzech wskazanych determinant w 42,4\%, natomiast pozostała część zmienności $Y(57,6 \%)$ nie została wyjaśniona przez czynniki z zakresu lokalnego rozwoju społeczno-gospodarczego. Zmienna $Y$ była więc powiązana także z innymi czynnikami, które nie zostały wzięte pod uwagę w badaniu lub miały charakter losowy.

W kolejnym badaniu przeprowadzono analizę regresji liniowej wielorakiej jedynie dla miast, w których systematyczny ubytek mieszkańców był większy niż 0,5\% rocznie. Co ciekawe, zmiennymi z zakresu lokalnego rozwoju społeczno-gospodarczego, które były istotnie powiązane 


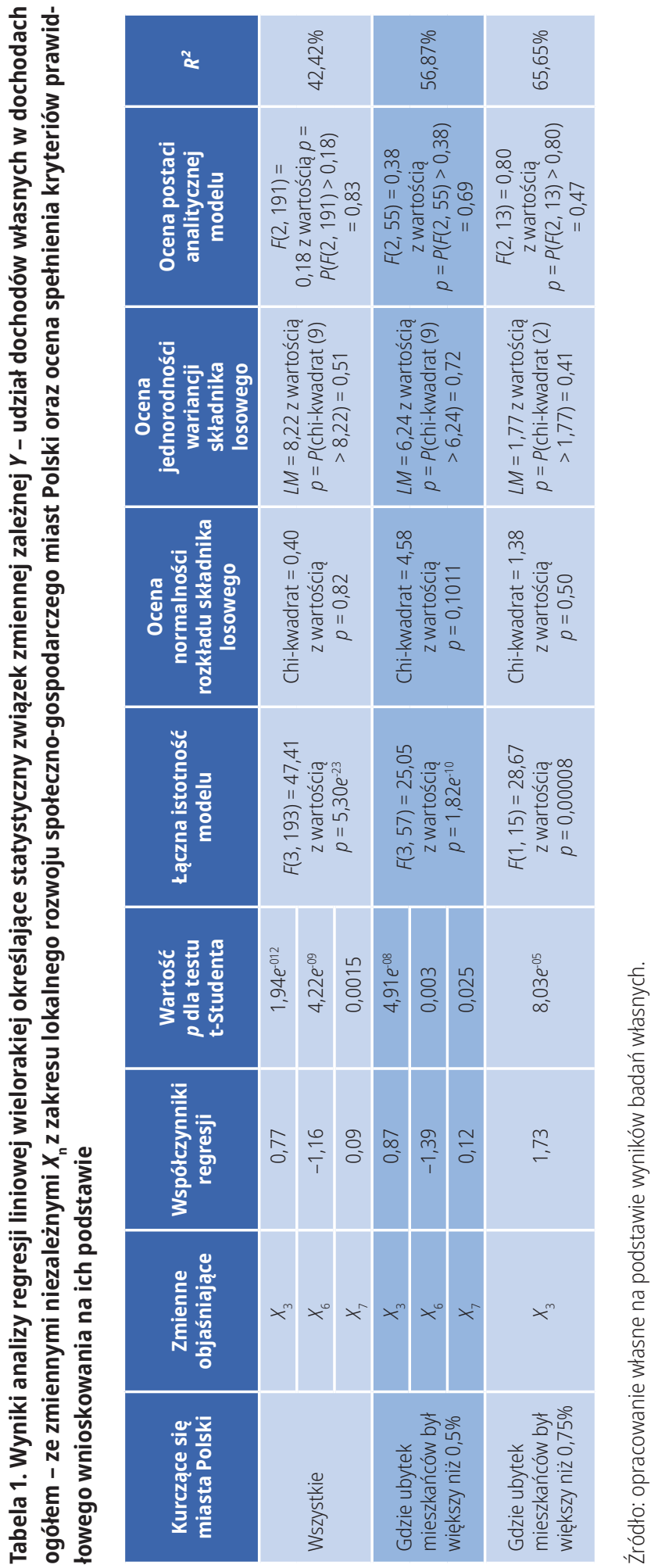


z udziałem dochodów własnych w dochodach ogółem, okazały się te same zmienne co w przypadku wszystkich kurczących się miast w Polsce. Do modelu nie weszła żadna z pozostałych potencjalnych zmiennych objaśniających. Równanie regresji liniowej wielorakiej można zapisać następująco:

$$
Y=43,94+0,87 X_{3}-1,39 X_{6}+0,12 X_{7}+e
$$

Interpretacja parametrów uzyskanego równania jest analogiczna do poprzedniego równania. Należy podkreślić, że wartość wszystkich parametrów równania jest wyższa niż w poprzednim modelu. Można zatem uzyskany wynik interpretować w ten sposób, że im większa była skala procesu kurczenia się miast w Polsce, tym udziały dochodów własnych w dochodach ogółem były silniej powiązane z czynnikami z zakresu lokalnego rozwoju społeczno-gospodarczego. Dodatkowo przemawia za taką interpretacją poziom współczynnika determinacji $R^{2}$, który był znacznie wyższy niż w przypadku analizy regresji dla całej grupy kurczących się miast. Wyniósł on 56,9\%, co oznaczało, że stopień wyjaśnienia zmiennej $Y$ przez trzy wskazane zmienne wzrósł o ok. 14,5 p.p.

W ostatnim badaniu analiza regresji liniowej wielorakiej została zawężona do miast, w których ubytek mieszkańców był znaczny i wynosił corocznie więcej niż 0,75\%. Takich ośrodków w Polsce w okresie badawczym było 17. W przypadku tej grupy jedynym czynnikiem statystycznie istotnie powiązanym ze zmienną $Y$ okazała się zmienna $X_{3}$ - liczba osób fizycznych prowadzących działalność gospodarczą na 100 osób w wieku produkcyjnym. Równanie regresji liniowej można zapisać następująco:

$$
Y=28,22+1,73 X_{3}+e
$$

Pomimo że do modelu weszła tylko jedna zmienna, stopień wyjaśnienia zmienności udziału dochodów własnych w dochodach ogółem przez zmienność liczby osób fizycznych prowadzących działalność gospodarczą na 100 osób w wieku produkcyjnym był wysoki. Współczynnik $R^{2}$ wyniósł bowiem $65,6 \%$. Oznacza to, że kluczowym czynnikiem z zakresu lokalnego rozwoju społeczno-gospodarczego powiązanym z dochodami własnymi w najbardziej kurczących się miastach była aktywność gospodarcza mieszkańców.

Na podstawie uzyskanych wyników badań własnych można stwierdzić, że dla dochodów własnych kurczących się miast kluczowymi determinantami z zakresu rozwoju społeczno-gospodarczego były te, które można zaliczyć do grup „przedsiębiorczość” oraz „rynek pracy”. Wraz z nasilającym się procesem ubytku mieszkańców dochody własne były coraz bardziej podatne na wymienione czynniki. Do modelu ekonometrycznego opisującego zależności dochodów własnych nie weszły natomiast czynniki z zakresu zagospodarowania przestrzennego ani czynniki społeczno-gospodarcze wyróżnione wśród potencjalnych zmiennych oddziałujących na dochody własne. 


\section{Podsumowanie}

Proces kurczenia się miast jest zjawiskiem powszechnym we współczesnym świecie. W Polsce dotyczy on zwłaszcza jednostek, które niegdyś miały charakter przemysłowy i są położone głównie w województwach: dolnośląskim, śląskim i łódzkim. Miasta te charakteryzują się występowaniem gałęzi przemysłów schyłkowych lub restrukturyzowanych oraz zmniejszającą się liczbą osób w nich pracujących. Po okresie rozkwitu te ośrodki przeżywają obecnie okres załamania zarówno gospodarczego, jak i społecznego (demograficznego) ze względu na wyczerpanie tradycyjnych zasobów lub utratę konkurencyjności na tle innych, obecnie rozwijających się miast.

Zjawisko kurczenia się miast jest więc ściśle powiązane z lokalnym rozwojem społeczno-gospodarczym danej jednostki. Zgodnie z wynikami badań zaprezentowanych w niniejszym artykule sytuacja gospodarcza i społeczna ośrodków miejskich ma wpływ na ich dochody własne. Kluczowe dla poziomu udziału dochodów własnych w dochodach ogółem analizowanych miast są bowiem czynniki determinujące lokalny rozwój społeczno-gospodarczy z zakresu przedsiębiorczości i rynku pracy. Najważniejszym z nich, niezależnie od stopnia nasilenia procesu kurczenia się miast, okazała się liczba osób fizycznych prowadzących działalność gospodarczą na 100 osób w wieku produkcyjnym, a więc aktywność ekonomiczna mieszkańców. Dwoma pozostałymi czynnikami, które wystąpiły w kurczących się miastach Polski, był udział zarejestrowanych bezrobotnych w liczbie ludności w wieku produkcyjnym oraz udział osób pracujących w liczbie ludności w wieku produkcyjnym. Wyniki badań są zgodne z konkluzjami zawartymi w przytaczanej w niniejszym opracowaniu literaturze przedmiotu. Wpływ zmian ludnościowych w miastach na ich finanse dokonuje się przez związek czynników z zakresu rozwoju społeczno-gospodarczego z klasycznymi determinantami dochodu narodowego wytwarzanego na terenie miast. Wśród tych determinant szczególne miejsce zajmuje podaż pracy oraz aktywność gospodarcza mieszkańców, a więc elementy tworzące bazę ekonomiczną miasta, która podlega opodatkowaniu, także podatkami lokalnymi.

Powyższe zmienne mogą stanowić sugestię dla władz lokalnych, które obszary rozwoju społeczno-gospodarczego powinny być szczególnie ważne w ich polityce, by zapewnić w kurczących się miastach odpowiedni poziom dochodów własnych, a przez to - ciągłość w zakresie ilości i jakości świadczonych usług publicznych oraz prawidłowe funkcjonowanie samorządności na terenie kurczących się miast. Rynek pracy i przedsiębiorczość są ze sobą ściśle związane i okazują się kluczowe w zakresie poprawy zarówno sytuacji finansowej miast, jak i lokalnego rozwoju społeczno-gospodarczego. Przykładami działań, które mogą stymulować oba te obszary, są inwestycje w infrastrukturę, np. drogową, organizacja szkoleń dla mieszkańców, popieranie inicjatyw społecznych, wykorzystanie środków unijnych na rozwój kapitału społecznego, tworzenie klimatu dla inwestycji prywatnych, większe zaangażowanie i propagowanie partnerstwa publiczno-prywatnego oraz współpracy z lokalnymi podmiotami gospodarczymi, odpowiednia oraz przejrzysta polityka finansowa gminy w zakresie ustalania stawek podatków i opłat lokalnych, a także przejrzyste reguły udzielania ulg i zwolnień oraz zamówień publicznych.

Kolejnym wyzwaniem badawczym, powiązanym ze zrealizowanymi badaniami, może być ocena determinant transferów rządowych skierowanych do kurczących się miast w kontekście 
lokalnego rozwoju społeczno-gospodarczego. Zaznaczono bowiem, że zależność od dotacji i subwencji w kurczących się miastach może rosnąć. Innym ciekawym kierunkiem badań, rzadko podejmowanych w literaturze przedmiotu - zarówno polskiej, jak i zagranicznej - może być wpływ procesu kurczenia się miast na stronę wydatkową budżetu oraz identyfikacja czynników na nią oddziałujących. Jak zauważono we wstępie, podejmowanie tego problemu jest aktualne i ważne w teoretycznym i praktycznym ujęciu.

\section{Informacja o realizacji badań}

Publikacja została napisana w wyniku odbywania przez autorkę stażu w Katedrze Finansów Publicznych, w Instytucie Finansów, w Kolegium Ekonomii, Finansów i Prawa na Uniwersytecie Ekonomicznym w Krakowie, współfinansowanego przez Unię Europejską w ramach Europejskiego Funduszu Społecznego (Program Operacyjny Wiedza Edukacja Rozwój), zrealizowanego w projekcie Program Rozwojowy Uniwersytetu Warmińsko-Mazurskiego w Olsztynie (POWR.03.05.00-00-Z310/17).

\section{Bibliografia}

Bănică A., Istrate M., Muntele I., Challenges for the Resilience Capacity of Romanian Shrinking Cities, „Sustainability” 2017, nr 9(12), 2289, https://doi.org/10.3390/su9122289.

Bernt M., Partnerships for Demolition: The Governance of Urban Renewal in East Germany's Shrinking Cities, „International Journal of Urban and Regional Research", t. 33, nr 3, https://doi.org/10.1111/j.1468-2427.2009.00856.x. Brooks C., Introductory Econometrics for Finance, Cambridge University Press, Cambridge 2008.

Burkholder S., The New Ecology of Vacancy: Rethinking Land Use in Shrinking Cities, "Sustainability” 2012, t. 4, nr 6, https://doi.org/10.3390/su4061154.

Coleman D., Rowthorn R., Who's Afraid of Population Decline? A Critical Examination of its Consequences, „Population and Development Review" 2011, t. 37, nr 1, https://doi.org/10.1111/j.1728-4457.2011.00385.x.

Döringer S., Uchiyama Y., Penker M., Kohsaka M.R., A Meta-Analysis of Shrinking Cities in Europe and Japan. Towards an Integrative Research Agenda „European Planning Studies” 2020, t. 28, nr 9, https://doi.org/10. 1080/09654313.2019.1604635.

Faust K.M., Abraham D.M., McElmurry S.P., Water and Wastewater Infrastructure Management in Shrinking Cities, „Public Works Management \& Policy” 2016, t. 21, nr 2, https://doi.org/10.1177/1087724X15606737.

Felis P., Możliwości oddziaływania władz samorządowych na wydajność wybranych kategorii źródeł dochodów własnych na przykładzie gmin w Polsce, „Finanse i Prawo Finansowe” 2014, nr 4.

Franz P., Shrinking Cities. Shrinking Economy? The Case of East Germany, "German Journal of Urban Studies” 2004, t. $43, \mathrm{nr} 1$.

Gornowicz M., Wichowska A., Struktura demograficzna a dochody gmin województwa warmińsko-mazurskiego w latach 2010-2014, "Społeczeństwo i Ekonomia” 2017, nr 1(7).

Großmann K., Bontje M., Haase A., Mykhnenko V., Shrinking Cities: Notes for the Further Research Agenda, "Cities" 2013, nr 35, https://doi.org/10.1016/j.cities.2013.07.007.

Haase A. et al., Conceptualizing Urban Shrinkage, „Environment and Planning A” 2014, t. 46, nr 7, https://doi. org/10.1016/j.landurbplan.2014.09.003. 
Hartt M., The Prevalence of Prosperous Shrinking Cities, „Annals of the American Association of Geographers”, t. 109, $\mathrm{nr}$ 5, https://doi.org/10.1080/24694452.2019.1580132.

Hollander J.B., Pallagst K., Schwarz T., Popper F.J., Planning Shrinking Cities, „Progress in Planning” 2009, t. 72, nr 4. Jaroszewska E., Urban Shrinkage and Regeneration of an Old Industrial City: The Case of Wałbrzych in Poland, "Quaestiones Geographicae" 2019, t. 38, nr 2, https://doi.org/10.2478/quageo-2019-0023.

Kazimierczak J., Szafrańska E., Demographic and Morphological Shrinkage of Urban Neighbourhoods in a Post-Socialist City: The Case of Łódź, Poland, "Geografiska Annaler: Series B. Human Geography” 2019, t. 101, nr 2, https://doi.org/10.1080/04353684.2019.1582304.

Long Y., Wu K., Shrinking Cities in a Rapidly Urbanizing China, „Environment and Planning A" 2016, t. 48, nr 2, https://doi.org/10.1177/0308518X15621631.

Marks-Bielska R., Lizińska W., Wojarska M., Raport z wykonania projektu badawczego. Sprawność instytucjonalna vs. Iokalny rozwój gospodarczy - czynniki kształtujące i interakcje, Olsztyn 2017, https://www.uwm.edu.pl/ konferencjakpgir/pliki/raport_z_projektu.pdf [dostęp: 4 listopada 2021 r.].

Martinez-Fernandez et al., Shrinking Cities in Australia, Japan, Europe and the USA: From a Global Process to Local Policy Responses, „Progress in Planning” 2016, nr 105, https://doi.org/10.1016/j.progress.2014.10.001.

Meade J.E., A Neo-Classical Theory of Economic Growth, Routledge Revivals, London 2013, https://doi. org/10.4324/9780203106631.

Pallagst K., Shrinking Cities in the United States of America. The Future of Shrinking Cities: Problems, Patterns and Strategies of Urban Transformation in a Global Context, University of California, California 2009.

Pallagst K., Wiechmann T., Martinez-Fernandez C., Shrinking Cities: International Perspectives and Policy iImplications, Routledge, New York-London 2013, s. 14.

Parysek J., Miasto w ujęciu systemowym, „Ruch Prawniczy, Ekonomiczny i Socjologiczny” 2015, t. 77, nr 1, https:// doi.org/10.14746/rpeis.2015.77.1.3.

Rieniets T., Shrinking Cities: Causes and Effects of Urban Population Losses in the Twentieth Century, „Nature and Culture" 2009, t. 4, nr 3, https://doi.org/10.3167/nc.2009.040302.

Schilling J., Logan J., Greening the Rust Belt: A Green Infrastructure Model for Right Sizing America's Shrinking Cities, „Journal of the American Planning Association" 2008, t. 74, nr 4, https://doi.org/10.1080/01944360802354956.

Seymour E., Endsley K.A., Franklin R.S., Differential Drivers of Rent Burden in Growing and Shrinking Cities, „Applied Geography", nr 125, 102 302, https://doi.org/10.1016/j.apgeog.2020.102302.

Simms A., Freshwater D., Ward J., The Rural Economic Capacity Index (RECI), a Benchmarking Tool to Support Community-Based Economic Development, "Economic Development Quarterly" 2014, t. 28, nr 4, https://doi. org/10.1177/0891242413512672.

Stryjakiewicz T., Jaroszewska E., The Process of Shrinkage As a Challenge to Urban Governance, "Quaestiones Geographicae" 2016, t. 35, nr 2, https://doi.org/10.1515/quageo-2016-0013.

Wiatrak A.P., Determinants of Local Development Strategies, „Acta Scientiarum Polonorum. Oeconomia” 2018, t. 17, nr 1, https://doi.org/10.22630/ASPE.2018.17.1.13.

Wichowska A., Demographic Determinants of Revenue Autonomy in Rural and Urban-Rural Municipalities, "Studia BAS" 2021, nr 1(65) [Źródła dochodów własnych jednostek samorzadu terytorialnego w Polsce, red. P. Felis, M. Korolewska], http://dx.doi.org/10.31268/StudiaBAS.2021.04.

Wichowska A., Determinanty budżetów gmin na przykładzie województwa warmińsko-mazurskiego, Wydawnictwo Uniwersytetu Warmińsko-Mazurskiego w Olsztynie, Olsztyn 2020. 
Wichowska A., Economic Aspects of Shrinking Cities in Poland in the Context of Regional Sustainable Development, „Sustainability” 2021, t. 13, nr 6, 3104, https://doi.org/10.3390/su13063104.

Wichowska A., Shrinking Municipalities and Their Budgetary Revenues on the Example of the Warmian-Masurian Voivodeship in Poland , „Oeconomia Copernicana” 2019, t. 10, nr 3, https://doi.org/10.24136/oc.2019.020.

Wojarska M., Marks-Bielska R., Lizińska W., Institution Efficiency versus the Level of Development of Local Governments (a Study at the Level of Poland's Regional Division), „Acta Scientiarum Polonorum. Oeconomia” 2018 t. 17, $\mathrm{nr}$ 2, https://doi.org/10.22630/ASPE.2018.17.2.29.

Wong C., Developing Indicators to Inform Local Economic Development in England, "Urban Studies” 2002, t. 39, nr 10, https://doi.org/10.1080/0042098022000002984.

\section{Akty prawne}

Konstytucja Rzeczypospolitej Polskiej z dnia 2 kwietnia 1997 r. (Dz.U. nr 78, poz. 483, ze zm.).

\section{Strony internetowe}

Bank Danych Lokalnych Głównego Urzędu Statystycznego, https://bdl.stat.gov.pl/BDL/.

Główny Urząd Statystyczny, Prognoza ludności na lata 2014-2050, https://stat.gov.pl/obszary-tematyczne/ludnosc/prognoza-ludnosci/prognoza-ludnosci-na-lata-2014-2050-opracowana-2014-r-1,5.html. 